\title{
ОПЛАТНІСТЬ КРЕДИТНОГО ДОГОВОРУ ЯК ОСНОВА ЕФЕКТИВНОСТІ КРЕДИТНИХ ПРАВОВІДНОСИН
}

\author{
ТЮФАНОВА Галина Олегівна - магістр міжнародного права (абітуріснтка \\ до аспірантури), Інститут міжнародних відносин Київського національного \\ університету імені Тараса Шевченка \\ ORCID: https://orcid.org/0000-0002-7305-2296 \\ DOI 10.32782/LAW.UA.2021.2.25
}

У статті аналізується питання оплатності як істотної умови кредитного договору. Зокрема, звертається особлива увага на те, щьо ефективність реалізацї кредитних правовідносин нерозривно пов'язана з можливістю виконання позичальником своїх зобов'язань щодо повернення кредиту та з положеннями, які закріпляють умови прочентних ставок.

y статті ретельно досліджуються аспекти правомірності одностороннъої зміни процентних ставок відповідно до положень кредитного договору через призму нормативно-правових актів, судової практики України та Европейсъкого суду з прав людини.

Окремо розглядається питання включення валютного застереження до кредитних договорів як положень, що можуть бути передумовою справедливої реалізацї умови ӥхньоі оплатності.

На основі здійсненого дослідження автор надає пропозииії з удосконалення національного законодавства відповідно до кращих підходів європейсъкої практики стосовно оплатності кредитного договору.

Ключові слова: кредитні правовідносини, кредитний договір, позичальник, кредитор, оплатність, одностороння зміна, процентна ставка, валютне застереження.

\section{Постановка проблеми}

Кредитні правовідносини $є$ одним 3 рушіїв ринкових механізмів держави, що, як деталь доміно, може запустити ряд незворотних процесів світової та національної економіки. Яскравим прикладом слугує сві- това криза 2008 року, яка була спричинена, зокрема, надмірною кількістю кредитних договорів, при укладенні яких не приділялась належна увага перевірці кредитоспроможності позичальників, не бралась до уваги об'єктивна нездатність останніх повернути кредитні кошти, а, відтак, встановлювались фактично неможливі для виконання умови процентних ставок. Як бачимо, ефективність реалізації кредитних правовідносин нерозривно пов'язана 3 виконанням позичальником своїх зобов'язань щодо повернення кредиту та з умовою оплатності кредитного договору.

Це підтверджується й останніми нормотворчими ініціативами протягом 20202021 років в Україні. Так, проводиться активна робота стосовно встановлення додаткових вимог до договорів про надання фінансових послуг, серед яких і кредитні договори. Така необхідність пов'язана 3 частим нерозумінням позичальниками умов кредитного договору, наприклад, стосовно реальної річної процентної ставки чи санкцій у випадку прострочки платежів, оскільки такі умови можуть зовсім не відображатись, якщо договір має форму договору приєднання. Так, наприклад, еже не раз в українських судах, зокрема й касаційної інстанції (постанова Верховного суду України від 3 вересня 2014 року у справі № 6-100цс14), поставало питання зменшення розміру штрафних санкцій, передбачених кредитним договором, як таких, що є непосильними для сплати пози- 
Тюфанова Г.О. - Оплатність кредитного договору як основа ефективності...

чальником та в рази перевищують розмір фактичних збитків [1].

Зазначене підтверджує, що питання оплатності кредитного договору має актуальність не лише з юридичної точки зору, а й $з$ точки зору ефективності реалізації кредитних правовідносин, зокрема і по відношенню до позичальника як слабшої сторони.

Метою статті є дослідження нормативного регулювання, судової практики та теоретичних напрацювань стосовно оплатності кредитного договору як основи ефективності реалізації кредитних правовідносин з метою розробки пропозицій для вдосконалення законодавства України, е тому числі спираючись на найбільш прогресивні іноземні та міжнародні нормотворчі практики.

\section{Аналіз літератури}

Питання оплатності кредитного договору досліджувались як вітчизняними, так i зарубіжними дослідниками, серед яких важливо виокремити О.І. Виговського, Г.Ф. Шершеневича, М.I. Брагінького та В.В. Вітрянського, І.Б. Новицького та I.С. Перетерського, Г. Дернбурга, О.С. Іоффе, А.Е. Бабаскіна, І.А. Безклубого, Д.І. Гравіна, А. Хадсона, Ж. Гавальду і К. Стуфле, Г.М. Бичкову та В.А. Боровинських, А.В. Шамраєва, Л.Г. Єфімову, С.П. Ємельянова, Бичкову Н.П., Авагяна Г.А., Криволапова Б.М. та інших.

\section{Виклад матеріалу}

Варто окремо зосередитись на опхатності як істотній умові кредитного договору з правової точки зору. Ч. 1 ст. 1054 Цивільного кодексу України (далі - ЦКУ) передбачає умову, що позичальник зобов'язується повернути кредит та сплатити проценти [2]. Крім того, відповідно до ч. 3 ст. 180 Господарського кодексу України (далі - ГКУ), при укладенні господарського договору сторони зобов'язані у будь-якому разі погодити предмет, ціну та строк дії договору, а у ч. 3 ст. 346 ГКУ зазначається, що надання безвідсоткових кредитів забороняється, крім випадків, передбачених законом [3].

Цікаво, що французькі дослідникиЖ. Гавальда і К. Стуфле відзначають, що, хоч «відплатність» 6 необхідною ознакою кредитного договору, однак окреме застереження в договорі не потрібне - головне, щоб сторони «не діяли безоплатно» [4, с. 18].

Те, як саме формується умова оплатності кредитного договору, має важливе значення для його справедливої реалізації на практиці. Це питання стосується, зокрема, можливості односторонньої зміни кредитором процентних ставок. Наразі кредиторам (у т.ч. банкам) чітко заборонено в односторонньому порядку змінювати умови укладених 3 клієнтами договорів, зокрема, збільшувати розмір процентної ставки. Однак, раніше це не було нормативно закріплено й часто практикувалось банками. Зміни відбулись на основі узагальнення практики Верховного суду України, коли у 2008 році було внесено ряд законодавчих правок як до ЦКУ, так і до Закону України «Про банки та банківську діяльність» [5], а саме Законом України «Про внесення змін до деяких законодавчих актів України щодо заборони банкам змінювати умови договору банківського вкладу та кредитного договору в односторонньому порядку» [6].

Однак, наголосимо, що така заборона діє стосовно зміни процентних ставок, яка не передбачена умовами договору. Якщо ж у договорі чітко прописано, що кредитодавець має право збільшувати процентну ставку, то вважається, що фактом підписання такого кредитного договору позичальник дав на це свою згоду. Відтак, таке збільшення $\mathrm{\epsilon}$ цілком законним, хоча не завжди справедливим і посильним для позичальника.

Це підтверджує тенденція до визнання несправедливості одностороннього збільшення процентної ставки, яке передбачене умовами кредитного договору, в інших країнах. Про це свідчить рішення Європейського суду з прав людини у справі «Merkantil Car Zrt. проти Угорщини» [7].

За обставинами справи, у 2014 році угорською владою було прийнято закон, який зі зворотною дією кАасифікував умови кредитних договорів про можливу односторонню зміну процентної ставки як несправедливі. Більше того, кредитори в цьому випадку повинні були відшкодувати різницю платежів внаслідок підвищення 
процентних ставок, а прибуток боржників внаслідок користування кредитами ніяк не враховувався. Кредитори після проходження всіх судових інстанцій звернулись до Европейського суду з прав людини (ЕСП $\Lambda$ ) щодо порушення конвенційних гарантій стосовно права на справедливий суд (ст. 6 Европейської конвенції 3 прав людини) та права на захист власності (ст. 2 Першого протоколу до Европейської конвенції з прав людини) [7].

ЕСП $\curlywedge$ не підтвердив порушення державою конвенційних положень, а, відтак, підтвердив презумпцію несправедливості умови кредитного договору щодо одностороннього підвищення процентної ставки [7].

Та попри прогресивну практику ЕСПЛ в українських реаліях продовжує діяти законодавчо дозволена практика одностороннього збільшення процентної ставки, якщо це передбачено кредитним договором. Щоправда, законодавець встановив певний запобіжник від маніпулювання кредитором питанням узгодженості сторонами односторонньої зміни процентних ставок - у випадку наявності кредитного договору, де таке право кредитодавця не закріплене.

У ч. 7 ст. 6 Закону України «Про фінансові послуги та державне регулювання ринків фінансових послуг» встановлюється, що у випадку, коли позичальник не погоджується на пропозицію фінансової установи щодо збільшення процентної ставки, останній заборонено вимагати дострокового погашення несплаченої частини боргу за кредитом та розривати в односторонньому порядку укладені кредитні договори [8].

Також варто враховувати той факт, що до ЦКУ та Закону України «Про банки і банківську діяльність» було внесені зміни щодо того, що «в період здійснення в Україні заходів щодо запобігання виникненню, поширенню і розповсюдженню епідемій, пандемій коронавірусної хвороби (COVID-19) забороняється підвищення процентної ставки за кредитним договором».

Крім того, Постановою №7 Правління Національного банку України від 22 січня 2021 р. було затверджено Положення про додаткові вимоги до договорів про надан- ня фінансових послуг (далі - Положення), серед яких знаходимо і договори надання споживчого кредиту (п. 2 Положення). Цим Положенням, зокрема, закріпляється 2 суттєві аспекти, що стосуються оплатності кредитного договору:

1) опис договорів про надання споживчого кредиту повинен містити умови, що дозволяють зміну процентної ставки або інших платежів за послуги кредитодавця, включених до загальних витрат за споживчим кредитом (п.П. 1 п. 10 Положення);

2) забороняється включати до договорів положення про односторонню зміну (згідно з договором або законами України) умов договору без фактичного надсилання повідомхення споживачу погодженим банком і споживачем каналом комунікації, що дає можливість встановити дату надсилання, з урахуванням особливостей, визначених Законом України «Про електронну комерцію» [9].

Отже, це положення хоч і вносить суттєві корективи та чіткість у формування договорів надання споживчого кредиту банками, але все ж не забороняє односторонню зміну процентної ставки як таку - лише встановлюе вимоги щодо наявності чітких умов зміни процентної ставки (відтак, і односторонньої в тому числі) та щодо обов'язкового включення до договору положення про інформування позичальника про односторонню зміну процентної ставки (що теж не є їі забороною).

Оплатність кредитного договору, як його істотна умова, часто супроводжується ще однією умовою, яка має комплементарний характер, - вахютним застереженням. Криволапов Б.М. визначає валютне застереження як «спеціальну умову договору, згідно 3 якою сума платежу повинна бути переглянута в тій самій пропорції, у якій відбудеться зміна курсу валюти платежу по відношенню до валюти застереження» [10].

Доцільність включення валютних застережень стала особливо очевидною під час уже згадуваної нами світової фінансової кризи 2008 року, яка призвела до девальвації національної валюти. Фактично, включення валютних застережень 3 прив'язкою визначення розміру платежів до курсу іноземної валюти є ефективним засобом страхування 
валютних ризиків, оскільки попри фіксацію у кредитному договорі обсягу зобов'язань позичальника купівельна спроможність грошей не є сталою й може змінюватись досить непередбачувано.

Можливість включення валютних застережень передбачена у ст. 524 ЦКУ, де зазначається, що «сторони можуть визначити грошовий еквівалент зобов'язання в іноземній валюті». У ст. 533 ЦКУ деталізується, що у випадку, якщо у зобов'язанні визначено грошовий еквівалент в іноземній валюті, сума, що підлягає сплаті у гривнях, визначається за офіційним курсом відповідної валюти на день платежу, якщо інший порядок iii визначення не встановлений договором або законом чи іншим нормативно-правовим актом.

Особливістю включення валютного застереження до кредитного договору є те, що у випадку, якщо боржник прострочить свої грошові зобов'язання за таким договором, то стягнення інфляційних нарахувань на суму основної заборгованості здійснюватися не може, оскільки індекс інфляції розраховується лише стосовно національної валюти України (гривні). На це звернув увагу Пленум Вищого господарського суду України у Постанові № 14 від 17.12.2013 року «Про деякі питання практики застосування законодавства про відповідальність за порушення грошових зобов'язань» [11].

Законодавчо неоднозначним є питання, за яким саме курсом іноземної валюти визначається сума, що підлягає сплаті. У статті 533 ЦКУ зазначається, що визначення відбувається за «офіційним курсом». Питання полягає в тому, чи можна вважати офіційним курсом лише курс НБУ. Відповідь на це питання знаходимо у постанові Вищого господарського суду України від 02.08.2017 р. у справі №916/4529/15 [12] та постанові Вищого господарського суду України від 19.01.2017 р.у справі №904/4782/16 [13], де підтвердилась теза про те, що сторони вільні визначити порядок розрахунку й зробити прив'язку, зокрема, і до курсу банку чи міжбанківського курсу.

Цікавою є судова практика Франції щодо застосування валютних застережень у кредитних договорах. Наприклад, Ка- саційний суд у рішенні № 16-13.050 від 29 квітня 2017 року прийшов до висновку, що валютне застереження може бути визнаним недійсним, у випадку, якщо воно може тягнути за собою обтяжливі наслідки для боржника. В інших судових рішеннях зазначалось, що валютне застереження може бути визнано судом недійсним, якщо:

1) валютне застереження може (чи могло) значно збільшити кредитну ставку i суму боргового зобов’ язання (що корелює із зазначеними обтяжливими наслідками для боржника);

2) кредитна організація не виконала свої обов' язки щодо консультування і надання повної інформації щодо валютних ризиків боржника (потенційних наслідків зміни валютного курсу) - це, зокрема, нерозривно пов'язується 3 необхідністю розкриття інформації стосовно складного механізму розрахунку валютних ризиків фізичній особi, яка не є професіоналом і не може самостійно об’єктивно оцінити всі ризики. При цьому кредитна організація звільняється від обов'язку щодо розкриття інформації розрахунку валютних ризиків у випадках, коли договір укладається 3 професійним учасником цивільного обороту [14].

\section{Висновки}

Дослідивши все вищезазначене, можемо зробити висновок, що умова оплатності кредитного договору $є$ його визначальною ознакою, яка впливає на ефективність кредитних правовідносин у цілому. Такий вплив проявляється ще на підготовчих етапах укладення кредитного договору, коли відбувається оцінка спроможності позичальника виконати умови щодо повернення кредиту, зокрема, за тими чи іншими процентними ставками, які будуть включені до договору. Підозра ж кредитора про нездатність божника виконати вже укладений договір за зазначеною в ньому ціною може призвести до вимоги про дострокове повернення кредиту, але в такому разі зобов'язання позичальника по сплаті процентів за наступні періоди, передбачені договором, припиняються.

Здійснений аналіз застосування односторонньої зміни процентної ставки, що 
передбачається договором, свідчить про несправедливість таких умов по відношенню до позичальника, попри легітимність 3 точки зору дійсного законодавства. Не можна заперечувати, що боржник надає свою згоду на таку односторонню зміну фактом підписання договору. Однак, попри це, на нашу думку, потрібно враховувати наступні особливості:

1) позичальник часто не має достатньої компетенції для оцінки ризику згоди 3 такою умовою договору (особливо якщо мова йде про споживче кредитування) - на відміну від кредитодавця, яким завжди виступає «професійний гравець» (банк чи інша кредитна установа);

2) позичальник часто не $є$ обізнаним 3 усіма положеннями кредитного договору щодо деталей оплатності, оскільки поширеною є практика укладення кредитних договорів у формі договорів приєднання (типових форм, заявок), коли позичальник

а) не може запропонувати власних умов - лише приєднатись до умов, які пропонує кредитодавець (у силу природи договору приєднання відповідно до ЦКУ);

b) часто недостатньо ознайомлений кредитором з умовами щодо оплатності кредитного договору - фактично підписує договір, де наявна відсилка до умов кредитування, розміщених на сайті банку.

Вищеописане разом з розглянутою практикою ЕСПЛ дозволяє нам зробити висновок про несправедливість односторонньої зміни умов оплатності кредитного договору, навіть якщо ним це передбачено. Доцільно вносити зміни до законодавства України, які 6 відобразили заборону на односторонню зміну процентних ставок у цілому.

Також вважаємо необхідним закріплення у законодавстві окремого обов'язку кредитодавця інформувати позичальника про суть валютного застереження. Зазвичай воно є вигідним саме для сторони кредитора, оскільки «девальваційні» процеси національної валюти збільшують фактичну суму платежів по кредитному договору для позичальника. Позичальник же може опинитися у ситуації необхідності сплати платежів, які можуть бути неспіврозмірно більшими у порівнянні з тими, на які він погоджувався при укладенні договору. Це логічно і з точки процедур оцінки кредитоспроможності позичальника, які до укладення кредитного договору спрямовані на визначення здатності позичальника здійснювати оплату за конкретними процентними ставками, а не за суттєво вищими після застосування валютного застереження.

Виходом могло б стати законодавче закріплення можливості позичальника відмовитись при укладенні кредитного договору від валютного застереження при умові того, що банк через це не відмовиться від кредитування. Але ця пропозиція може розцінюватись як надто обтяжлива для банків, якщо таку можливість використовуватимуть більшість позичальників, особливо в період фінансових криз. Тому закріплення обов'язку належної комунікації кредиторів 3 позичальниками щодо змісту валютних застережень може зняти хоча би ризик відсутності повного усвідомлення боржником своїх зобов'язань.

Подальше вдосконалення розглянутих у цій роботі проблематичних питань оплатності як умови кредитного договору є запорукою ефективності кредитних правовідносин, оскільки не можна назвати ефективним механізм, де одна зі сторін правочину часто лишається сам на сам із надто обтяжливими, а іноді й непосильними, обов'язками які не передбачались такою стороною при вступі у кредитні правовідносини.

1. Постанова Верховного суду України у справі № 6-100цс14 від 3 вересня 2014 року URL: https://reyestr.court. gov.ua/Review/40423567 (дата звернення: 12.06.2021 p.).

2. Цивільний кодекс України (Закон України № 435-IV від 16.01.2003). URL: https://zakon.rada.gov.ua/laws/show/43515\# Техt (дата звернення: 10.06.2021р.).

3. Господарський кодекс України (Закон України № 435-IV від 16.01.2003). URL: https://zakon.rada.gov.ua/laws/show/43615\#Text (дата звернення: 10.06.2021р.).

4. Бычкова Н.П., Авагян Г.А., Баяндурян Г.А. Кредитный договор: экономическая и правовая природа. Москва, 2009 р. $159 \mathrm{c}$ 
5. Закон України «Про банки та банківську діяльність» № 2121-III від 07.12.2000 p. URL: https://zakon.rada.gov.ua/ laws/show/2121-14\#Tехt (дата звернення: 23.06.2021 р.).

6. Закон України «Про внесення змін до деяких законодавчих актів України щодо заборони банкам змінювати умови договору банківського вкладу та кредитного договору в односторонньому порядку» № 661-VI від 12.12.2008 р. URL: https://zakon.rada.gov. ua/laws/show/661-17\#Text (дата звернення: 03.06.2021 p.).

7. MERKANTIL CAR ZRT. against Hungary and 4 other applications. Application № 22853/15. 27.11.2018. URL: https://hudoc.echr.coe.int/eng\#\{\%22item id\%22:[\%22001-188980\%22]\} (Last accessed: 07.06.2020).

8. Закон України «Про фінансові послуги та державне регулювання ринків фінансових послуг» № 2664-III від 12.07.2001 p. URL: https://zakon.rada.gov.ua/ laws/show/2664-14\#Tехt (дата звернення: 05.06.2021 p.).

9. Постанова Правління Національного банку України «Про затвердження Положення про додаткові вимоги до договорів про надання фінансових послуг» №7 від 22 січня 2021 p. URL: https://zakon.rada.gov.ua/ laws/show/v0007500-21\#Text (дата звернення: 07.06.2021 р.).

10. Криволапов Б. М. Валютні застереження в міжнародному приватному праві. Актуальні проблеми міжнародних відносин. 2011. № 99(2). С. 109-114. URL: http://journals.iir.kiev.ua/index.php/apmv/ article/viewFile/1591/1507 (дата звернення: 11.06.2021 p.).

11. Постанова Пленуму Вищого господарського суду України «Про деякі питання практики застосування законодавства про відповідальність за порушення грошових зобов’язань» № 14 від 17.12.2013 р. URL: https://zakon.rada.gov.ua/laws/show/v001460013\#Text (дата звернення: 11.06.2021 р.).

12. Постанова Вищого господарського суду України у справі №916/4529/15 від 02.08.2017 р. URL: https://reyestr.court.
gov.ua/Review/68108626 (дата звернення: 11.06.2021 p.).

13. Постанова Вищого господарського суду України у справі №904/4782/16 від 19.01.2017 p. URL: https://reyestr.court. gov.ua/Review/64199652 (дата звернення: 11.06.2021 p.).

14. Договоры займа и кредитные договоры. Регулирование и судебная практика во Франции. Аналитическая справка. Центр международных и сравнительно-правовых исследований. Москва. 2018 г. URL: https:// iclrc.ru/files/events/38/\%D0\%A4\%D1\%80\%D 0\%B 0\% D0\%BD\% D 1\%86\% D0\% B 8\% D 1\%8F.

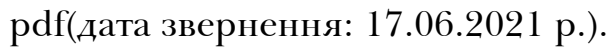

\section{REPAYMENT OF THE LOAN AGREEMENT AS THE BASIS OF EFFICIENCY OF LENDING RELATIONSHIP}

The article analyzes the issue of repayment as an essential condition of the loan agreement. Special attention is paid to the fact that the effectiveness of the implementation of lending relationship is inextricably linked with the ability of the borrower to discharge its obligations to repay the loan and with the provisions that set the terms of interest rates.

The article elaborately examines aspects of the legality of unilateral changes in interest rates in accordance with the provisions of the loan agreement in concordance with legislative acts, judicial practice on this issue in Ukraine and judicial opinion of the European Court of Human Rights.

The article separately considers the issue of including a currency clause in loan agreements, which may be a prerequisite for the fair implementation of the terms of their repayment.

Based on the research, the author provides suggestions for improving national legislation in accordance with the best approaches of european practice regarding the repayment of the loan agreement.

Key words: lending relationship, loan agreement, borrower, lender, repayment, unilateral change, interest rate, currency clause. 


\author{
ВІДГУК \\ на наукову роботу \\ студентки II курсу магістратури \\ відділення «Міжнародне право» \\ Інституту міжнародних відносин \\ Київського національного університету імені Тараса Шевченка \\ Тюфанової Галини Олегівни \\ на тему:
}

«Оплатність кредитного договору як основа ефективності реалізації кредитних правовідносин»

Дана науково-дослідницька робота присвячена надзвичайно актуальній темі. У ній грунтовно розкриваються правові аспекти оплатності як істотної умови кредитного договору та його ключової характеристики, що визначає специфіку кредитних правовідносин. 3 огляду на необхідність вдосконалення банківського законодавства та триваючий процес рекодифікації цивільного законодавства України, який передбачає, зокрема, оновлення нормативного масиву щодо окремих видів договорів, звернення Тюфанової Галини Олегівни до даної проблематики уявляється більш ніж своєчасним та доцільним.

Актуальність обраної теми дослідження обумовлена необхідністю наукової розробки окремих питань застосування кредитного договору з метою належного захисту прав та інтересів як позичальників, так і кредитодавців, вдосконалення механізму правового регулювання кредитних відносин та наближення українського законодавства у цій сфері до кращих європейських стандартів. У роботі піднімаються такі важливі питання, як форма оплатності кредитного договору, зміна розміру процентних ставок кредитодавцем в односторонньому порядку, пред'явлення кредитодавцем вимоги про дострокове повернення кредиту, застосування валютного застереження як спеціальної умови кредитного договору.

Дослідження грунтується на узагальненні доктринальних поглядів, регуляторного та практичного досвіду, а також широкого масиву судової практики (включаючи рішення Європейського суду з прав людини) в обраній галузі дослідження. Дана робота носить комплексний характер і має очевидне теоретичне значення та практичну спрямованість. Висновки, представлені наприкінці роботи, мають важливе теоретичне та прикладне значення, містять ознаки наукової новизни та авторського бачення шляхів вирішення нагальних питань сучасної цивілістичної доктрини.

У цілому, можна зробити висновок, що зазначена науково-дослідницька робота Тюфанової Галини Олегівни виконана на високому теоретичному рівні, являє собою повністю самостійне та комплексне наукове дослідження у сфері правового регулювання кредитних договорів. 3 огляду на викладене вище, дана науково-дослідницька робота може бути рекомендована для участі в конкурсі Стипендіальної програму завтра.ЧАј фонду Віктора Пінчука.

Науковий керівник

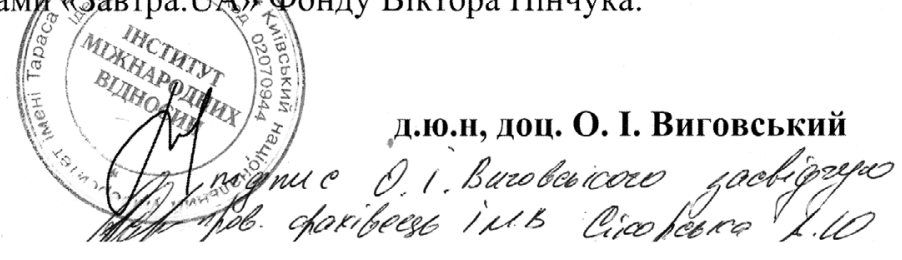

Право.ua № 2, 2021 